\title{
The importance of corporate governance
}

\author{
Mudji Utami \& Bertha Silvia Sutejo \\ University of Surabaya, Surabaya, Indonesia
}

\begin{abstract}
This research examines the impact of corporate governance (CG) towards financial distress and financial performance. This paper used historical data from non-financial sector companies listed on Indonesia Stock Exchange (IDX) on the period 2011-2016. Corporate governance variables used in this research are managerial ownership, investor institutional, auditor opinion, and independent director. This study uses quantitative approach by using linear and logic regression. Final sample used in this study are 331 companies. Using a 5 percent significance level, the study found that there is a significant relationship between institutional ownership, independent director, and audit opinion to financial performance. While this study shows only independent directors who have a significant influence on financial distress.

Keywords: corporate governance, financial distress, financial performance
\end{abstract}

\section{INTRODUCTION}

The rivalry in business which is increasingly competitive requires firms to be able to increase the values for shareholders as well as stakeholders. One of the criteria of the success of a company is determined by the practice of good corporate governance in the company's management. According to Black et al. (2006) and Hodgson et al. (2011) the practice of good corporate governance strengthens the company's performance and protects the company from the risk of financial distress. (Parker et al. 2002, Wang \& Deng 2006). The research of Hambrick \& D' Aveni (1992) and Daily \& Dalton (1994) also found that the weak practice of CG tends to be related to the company's bankruptcy.

Corporate governance is a foundation that lead and control a corporate with the purpose of achieving balance between strength and the company's authority in providing accountability to the shareholders and stakeholders (Daniri 2005). Keasey \& Wright (1993) explained that corporate governance is a structure, process, culture, and system that generates operational success of an organization. In general, the quality of corporate governance can be evaluated based on the openness and transparency principles, the relation of the shareholders and the stakeholders, the characteristics of the board of directors, the policy and obedience, and the ownership and control structure. Manzaneque et al. (2016) found that the effectiveness of corporate governance can be evaluated by observing the management and the focus on long term performance. The influence of institutional ownership on financial distress shows that institutional investor has an important role in controlling the management. Institutional investors have some influence in the sustainability of a

company because they have active role in control- ling the company. Therefore, the higher the institu- tional ownership, the lower the chance of the com- pany experiencing financial distress. The research of Miglani et al. (2014), and Manzaneque et al. (2016) also found a negative relation between the institutional ownership with financial distress. Mubarak \& Ahmed-Haji (2014) shows that ownership institution has a significant negative influence on the company's performance.

Suntaruk (2009) suggested that incentive may influence the directors to think like the company's shareholders. When the ownership of the management on the company share is not much, the managerial ownership does not have the incentive to align the objective to the owner's objective because the management is not involved in the financial result of the manager's decision. However, if the manage- ment has a significant amount of share, the man-agement will try to increase the welfare of the share- holders, including himself. Therefore, the higher the share ownership in a company by management, the lower the chance of the company to experience fi- nancial distress. Li et al. (2008) and Suntaruk (2009) found that there is a negative relation be- tween managerial ownership and financial distress. Sheikh et al. (2013) also found that managerial own- ership has a significant negative influence on the company's performance. The management that pos- sess the company's share often abuses the compa- ny's resources for personal gain, so it may decrease the company's performance. 
Independent director is beneficial in monitoring and controlling opportunists, as well as avoiding management's behavior in making decisions which are consistent with the shareholders. A company with higher proportion of independent directors may reduce the chance of financial distress. Therefore, the higher the number of independent directors, the lower the chance of financial distress. Manzaneque et al. (2016) also shows a negative relation between independent director and financial distress. Kouki \& Guiziani (2015) found that there is a positive influence of independent director towards financial performance. The more unaffiliated independent director, the better the performance of a company.

Miglani et.al. (2015) and Murhadi (2009) shows that auditor opinion is a dummy variable with the score "1" which indicates that the result of auditor opinion is not satisfactory (there is a nonconformity of the financial report and the prevailing standards), and the score " 0 " which indicates the result of the auditor opinion is satisfactory (the financial report is acceptable with no exception). Unsatisfactory audit opinion is a negative signal for the company's financial and a sign of hidden risks within the company. Unsatisfactory Audit opinion leads to a higher chance of financial distress. Li et al. (2008) and Miglani et al. (2014) found a positive relation between audit opinion and financial distress. Buallay et al. (2017) also found that audit quality has a significant positive influence on the company's performance.

Size shows the magnitude of a company. A big size company will easily get funding from internal or external sources to fund the beneficial investment opportunities, and the company has the ability to fulfil all the financial obligations. Miglani et al. (2014) found a negative relation between the size of a company with financial distress. Palmon \& Wald (2002) also stated that the size of a company may influence the company's performance because it is related to a better leadership structure. Ehikioya (2009) shows that firm size has a significant positive influence on the financial performance. Pervan \& Visic (2012) also stated that the growth of the size of the company will result in the company's profitability.

Financial leverage shows the amount of debt that a company has to finance the operational activity and the investments. The higher the leverage in a company, the bigger the chance of default, so the chance of financial distress increases. Shahwan (2015) and Li et al. (2008) found a positive relation between financial leverage and financial distress. Vo \& Phan (2013), on the other hand, found that leverage has a negative influence on financial performance. The high amount of debt will put a company in a position which has higher risk and existence threatening for the company if there is a default. Leverage can be used to improve profitability if it is used to develop a business. However, it is always linked to the risk of increasing the loss during difficult times. In other words, profit and loss will be bigger with the use of leverage.

Based on the explanation above, the purpose of this research is to test: (1) whether institutional investor has any influence on financial distress and financial performance on the companies listed in BEI within 2011-2016, (2) whether managerial ownership has any influence on financial distress and financial performance on the companies listed in BEI within 2011-2016, (3) whether independent director has any influence on financial distress and financial performance on the companies listed in BEI within 2011-2016, (4) whether auditor opinion has any influence on financial distress and financial performance on the companies listed in BEI within 20112016.

\section{RESEARCH METHODS}

The data source of this research used external data from the companies listed in the Indonesian Stock Exchange within 2011-2016. The sample of the research was the company that had financial reports which were audited continuously during the research period.

The dependent variable was the financial performance measured from the Return on Assets (ROA), and financial distress measured using Multivariate Discriminant Analysis (MDA). The stages of MDA were as follows: First, dividing companies into two groups: group of companies experiencing distress and group of companies not experiencing distress (healthy). Secondly, testing variables of corporate governance which were most dominant on financial distress. Thirdly, producing Z-score model to find out the companies that experiencing financial distress and companies not experiencing financial distress with the conditions that the dummy variable of the healthy company was given " 0 " with a Z-score above 2.90 , but the dummy variable of the unhealthy company was marked " 1 " with the Z-score below 1.98. The independent variables include institutional ownership, managerial ownership, independent directors, and auditor opinion. While the control variables include firm size and financial leverage.

There were two analysis techniques such as regression logistic and multiple regression. Regression logistic was used to analyze financial distress, and multiple regression was used to analyze financial performance. 


\section{RESULTS AND DISCUSSIONS}

Table 1. Result of Regression Financial Performance

\begin{tabular}{lcc} 
Variable & 1 & S1g \\
\hline Institutional Ownership & 1,953 & $0,051^{* * *}$ \\
Managerial Ownership & -0.663 & 0.508 \\
Independent Director & $-2,069$ & $0,039^{* *}$ \\
Audit Opinion & $-2,439$ & $0,015^{* *}$ \\
Size & $-0,081$ & 0,936 \\
Financial Leverage & 3,262 & $0,001^{*}$ \\
\hline
\end{tabular}

Note: * significant $\alpha=1 \%, * *$ significant $\alpha=5 \%, * * *$ significant $\alpha=10 \%$

Based on Table 1, it is proven that Institutional ownership has a significant positive influence on financial performance. It means that the increase of the amount of share of the institution in the company will improve financial performance. Amyulianthy (2012) stated that this condition happens because the institution will professionally monitor the development of the investment, so the level of control on the management actions is very high, and any potential ruse can be minimized. Managerial ownership is proven not to have significant influence on the financial performance of the company. It is because the performance of a company depends on the amount of asset, efficiency, and effectiveness in managing the resources.

Independent director also has a significant negative influence on financial performance. It means that the increasing number of board of independent commissioner will improve the company's performance. Yermack (1996 in Susiani 2012) stated that it happens because the competence of board of independent commissioner that is inadequate, so the profitability or the financial performance is degrading. The result of the study is consistent with the research of Susiani (2015) and Ahmed Haji \& Mubarak (2015) who found that the board of independent commissioner has a significant negative influence on the return on asset.

Auditor opinion is proven to have a significant negative influence on financial performance. It is consistent with the result of the research conducted by Amyulianthy (2012) who found that audit quality has a significant positive influence on the company's financial performance. Haat et al. (2008) stated that the reputation of Big Four does not have significant influence for the investor in investing on the related company. The company also spends too much in using the service of KAP which is the member of the Big Four, and has a poor performance. Hassan \& Halbouni (2013) also stated that external audit does not influence the operational decision of the company being audited.

Financial leverage as a control variable is proven significant on the performance of the company, while the size is not proven significant.
Table 2. Result of Regression Financial Distress

\begin{tabular}{ll} 
Variable & Sig \\
\hline Institutional Ownership & 0,844 \\
Managerial Ownership & 0,255 \\
Independent Director & $0,003^{*}$ \\
Audit Opinion & 0,103 \\
Size & $0,013^{* *}$ \\
Financial Leverage & $0.000^{*}$
\end{tabular}

Note: * significant $\alpha=1 \%, * *$ significant $\alpha=5 \%, * * *$ significant $\alpha=10 \%$

Table 2 shows that Institutional Ownership is insignificant on financial distress. It means that institutional ownership does not have influence on financial distress, similar to managerial ownership and audit opinion which have insignificant result on financial distress. The result is not consistent with the research of Suntaruk (2009), Li et al. (2008), Sheikh et al. (2013), Manzaneque et al. (2016), and Buallay et al. (2017).

The significant result is only on the Independent director. Independent director has a significant influence on financial distress which is consistent with the research of Manzaneque et al. (2016) and Kouki \& Guiziani (2015). Independent director can monitor and control the opportunists and avoid the management in making decision which is consistent with the shareholders. A company with the higher proportion of independent director can reduce the possibility of financial distress. The more the number of unaffiliated independent directors, the better the monitor and the improvement of company performance, which reduce the risk of financial distress. Financial leverage and size as the control variable are proven to have significant influence on financial distress.

\section{CONCLUSIONS}

The result of the research shows that corporate governance has significant influence on financial performance, but it does not have significant influence on financial distress. Corporate governance is measured through institutional ownership, managerial ownership, independent director, and audit opinion. Institutional ownership, independent director, and audit opinion have a significant influence on financial performance. Meanwhile, managerial ownership is not proven to have a significant influence on financial performance. In addition, the result of financial distress shows that only independent director has influence on financial distress while others do not have any influence. 


\section{REFERENCES}

Black, B.S., Jang, H. \& Kim, W. 2006. Does corporate governance predict firm's market values? Evidence from Korea. Journal of Law, Economics and Organization 22(2): 366413

Buallay, A., Hamdan, A. \& Zureigat, Q. 2017. Corporate governance and firm performance: evidence from Saudi Arabia. Australasian Accounting, Business and Finance Journal 11(1): 78-98.

Daily, C.M. \& Dalton, D.R. 1994. Bankruptcy and corporate governance: the impact of board composition and structure. Academy of Management Journal 37(6): 1603-1617

Daniri, M.A. 2005. Good corporate governance: Konsep dan penerapannya dalam konteks Indonesia. Jakarta: Ray Indonesia.

Ehikioya, B.I. 2009. Corporate governance structure and firm performance in developing economies: evidence from $\mathrm{Ni}$ geria. Corporate Governance. The international journal of business in society 9(3): 231-243.

Hambrick, D.C. \& D'Aveni, R.A. 1992. Top team deterioration as part of the downward spiral of large corporate bankruptcies. Management Science 38(10): 1445-1466

Hodgson, A., Lhaopadchan, S. \& Buakes, S. 2011. How informative is the Thai corporate governance index? A financial approach. International Journal of Accounting and Information Management 19(1): 53-79.

Keasey, K \& Wright, M. 1993. Issues in corporate accountability and Governance. Accounting and Business Research 23, 291-303.

Kouki, M. \& Guizani, M. 2015. Outside Directors and Firm Performance: The Moderating Effects of Ownership and Board Leadership Structure. International Business Research 8(6): 104-116.

Li, H.X., Wang, Z.J. \& Deng, X.L. 2008. Ownership, Independent Directors, Agency Costs And Financial Distress: Evidence From Chinese Listed Companies. Corporate Governance: The International Journal of Business in Society.

Manzaneque, Montserrat, Priego, Alba M., \& Elena Merino. 2016. Corporate Governance Effect on Financial Distress Likelihood: Evidence from Spain. Revista de Contabilidad Spanish Accounting Review 19 (1): 111-121

Miglani, S., Ahemd, K. \& Henry, D. 2014. Voluntary Corporate Governance Structure and Financial Distress: Evidence from Australia. Journal of Contemporary Accounting \& Economics 11: 18-30

Mubaraq, A. \& Ahmed-Haji, A. 2014. The impact of corporate governance attributes on intellectual capital disclosure: A longitudinal investigation of Nigerian banking sector. Journal of Banking Regulation 15(2): 144-163.

Murhadi, W.R. 2009. Studi pengaruh good corporate governance terhadap praktik earnings management pada perusahaan terdaftar di PT Bursa Efek Indonesia. Jurnal Manajemen dan Kewirausahaan 11(1).

Palmon, O. \& Wald, J.K. 2002. Are two heads better than one? The impact of changes in management structure on performance by firm size. Journal of Corporate Finance 8(3): 213-226

Parker, S., Peters, G.F. \& Turetsky, H.F. 2002. Corporate governance and corporate failure: a survival analysis. Corporate Governance: International Journal of Business in Society 2(2): 4-12

Pervan, M. \& Visic, J. 2012. Influence of Firm Size On Its Business Success. Croatian Operational Research Review 3.
Shahwan, T.M. 2015. The effects of corporate governance on financial performance and financial distress: evidence from Egypt. Corporate Governance 15(5): 641 - 662.

Sheikh, N.A., Wang, Z. \& Khan, S. 2013. The impact of internal attributes of corporate governance on firm performance: Evidence from Pakistan. International Journal of Com- merce and Management 23(1): 38-55.

Suntraruk, P. 2009. Predicting Financial Distress: Evidence from Thailand. Proceedings of the European Financial Management Association 2009 Annual Meeting. Milan, Italy, June 24-27.

Vo, H.D. \& Phan, B.G.T. 2013. Corporate governance and firm performance: Empirical evidence from listed companies on Ho Chi Minh City Stock Exchange. UEH Journal of Economic Development, 275: 1-15

Wang, Z.J. \& Deng, X.L. 2006. Corporate governance and financial distress: evidence from Chinese listed companies. The Chinese Economy 39(5): 5-27 